\title{
The Effect of Foreign Acquisition on Employment and Wages: Evidence from Finnish Establishments
}

\author{
Kristiina Huttunen \\ University of Helsinki and HECER
}

Discussion Paper No. 62

May 2005

ISSN 1795-0562

HECER - Helsinki Center of Economic Research, P.O. Box 17 (Arkadiankatu 7), FI-00014 University of Helsinki, FINLAND, Tel +358-9-191-28780, Fax +358-9-191-28781,

E-mail info-hecer@helsinki.fi, Internet www.hecer.fi 


\title{
The Effect of Foreign Acquisition on Employment and Wages: Evidence from Finnish Establishments*
}

\begin{abstract}
This paper examines the effect of foreign acquisition on wages and employment of different skill groups using panel data on Finnish establishments for 1988-2001. Exploiting the availability of a rich set of pre-acquisition controls, we use various regression and propensity score matching methods. The results indicate that foreign acquisition has a positive effect on wages. The magnitude of this effect increases with the level of schooling of the workers. The wage increase is not immediate, but happens within 1-3 years from the acquisition. Surprisingly, the results indicate that acquired plants reduce the share of highly educated workers in their employment.
\end{abstract}

JEL Classification: C33, F16, F23, J31

Keywords: Foreign acquisition, wages, employment, education, propensity score matching, panel data.

\author{
Kristiina Huttunen \\ University of Helsinki \\ Department of Economics \\ P.O. Box 17 (Arkadiankatu 7) \\ FI-00014 University of Helsinki \\ FINLAND
}

e-mail: kristiina.huttunen@helsinki.fi

\begin{abstract}
* I want to thank Tor Eriksson, Donatella Gatti, Pekka IImakunnas, Steve Machin, Tuomas Pekkarinen, Kjell G. Salvanes and Roope Uusitalo for their comments, as well as participant in seminars at University College London, University of Oxford, University of Helsinki and in the conferences "Globalization- Implications to Labour Market and Welfare Policies" in Aarhus, 2004, and "Panel Data 2004" in College Station, Texas. Financial support from Yrjö Jahnsson Foundation and Finnish Cultural Foundation is gratefully acknowledged.
\end{abstract}




\section{Introduction}

In recent years, several studies have documented that the foreign-owned firms tend to pay higher wages than the domestically-owned firms. ${ }^{1}$ This finding has potentially important implications since, partly as a result of increased globalization, the number foreign-owned firms is growing in many countries. However, the direction of causality between foreign ownership and wages remains unclear. We do not know whether foreign investors acquire skill-intensive firms that pay high wages or whether the foreign ownership, in itself, has a genuine positive effect on wages and the skill-structure of the firms. Moreover, little is known about the heterogeneity of the effect of foreign ownership on wages of workers in different skill groups.

In this paper, we use rich Finnish plant-level panel data with matched information on the worker characteristics of the plants to study the effect of foreign acquisition on employment and wages. This study aims to contribute to the literature in three ways. First of all, we argue that these data allow us to disentangle the direction of causality more carefully than has been done in previous studies. In particular, we use various propensity score matching methods, including the difference-in-differences matching developed by Heckman et al (1997), in addition to more traditional regression techniques. The central idea in these methods is to base the estimation of the effects on a careful matching of cases and controls by a rich set of observable characteristics. Second, the matched information on the employee characteristics by skill groups makes it possible to disentangle the effect of foreign ownership on wages from its effects on the quality of the work force. Furthermore, this information allows us to examine the heterogeneity of the effect of foreign acquisition on wages and employment. Third, the long time-span of our data, 13 years, enables us to look at the effects of foreign acquisition in the long-run. Hiring and firing costs may be delay the effects of foreign acquisition. By looking at the effects of acquisition in several periods after it has taken place, we can take these delays into account.

We believe that Finland is an interesting case study for the effects of for-

\footnotetext{
${ }^{1}$ See e.g. Aitken et al., 1996, Lipsey and Sjöholm, 2001, 2003, and Conyon et al., 2001
} 
eign ownership. It is a typical example of a small open economy where the foreign investment plays an important role. Furthermore, our data cover the years 1988-2001 in which the share of foreign direct investments rose rapidly in Finland. This increase is depicted in figure 1 and it partly reflects the worldwide trend in foreign direct investment. But the years 1988-2001 were also an interesting period in the Finnish economic history that marked two phenomena that undoubtedly led to the increase in the share of foreignowned firms. First, in the early 1990's Finland experienced a very severe recession and the recovery from this crisis was associated with a rapid restructuring of the economy and a growth of new industries: in particular, the export-orientated high-tech sector. ${ }^{2}$ Second, Finland joined the European Union in 1995, which naturally removed a lot of barriers to foreign investment in the Finnish economy.

The results derived by both matching and regression methods indicate that foreign acquisition has a positive effect on wages in all the skill groups. This wage increase is not immediate, but happens within 1-3 years from the acquisition. The magnitude of this effect increases with the level of schooling of the workers. The foreign-owned firms reduce, albeit slightly and slowly, the share of highly educated workers in their work force. However, the highly educated workers that remain in the acquired plants are paid considerably more than the identical workers in domestically-owned plants.

The paper is organized as follows: Next section briefly describes the theoretical background for the analysis and reviews some previous empirical findings. Third section describes the statistical framework. Fourth section presents the data sets. Fifth section provides the results. The last section concludes the paper.

\section{Background and Previous Evidence}

There are several possible reasons why foreign-owned firms pay higher wages than domestically-owned firms. First, foreign firms need to possess some firm-specific advantages, such as superior technology, in order to be able

\footnotetext{
${ }^{2}$ see Honkapohja and Koskela. (1999)
} 
to compete with local firms ${ }^{3}$. These assets are assumed to raise the productivity of the firms. Assuming that workers can bargain over any surplus generated, higher productivity would be expected to generate a greater surplus and hence higher wage rates ${ }^{4}$. Second, workers employed by the multinational enterprise acquire knowledge of the superior technology and can spread their knowledge to local firms by switching employers. Foreignowned firms might pay higher wages in order to prevent workers from moving to local competitor and spillover this superior knowledge (See Fosfure et al. 2001.). Third, the knowledge-based assets that foreign-owned firms are assumed to have require better trained workers (see Görg, 2001). Workers in foreign-owned firms are assumed to receive more training and, as a result, have steeper wage profiles than workers in domestic firms. Fourth, foreign firms might have size and communication problems compared to domestic firms. They might seek industrial relations peace with higher wages (see e.g. Conyon et al., 2002).

The direct effect of foreign ownership on the relative wages and skill demand is not clear. There are, however, indirect ways how multinational enterprises can influence the skill demand within a country, industry or a plant. Foreign firms entering an industry will accelerate the rate of technological progress. This, in turn, will increase the relative demand and wages for highly skilled workers in that industry (see e.g. Taylor and Driffield, (2004). Foreign acquisition is also assumed to be associated with reorganization of existing capacity and introduction of new ideas within the new plants. The organizational change is expected to raise the demand for skilled labour, since skills raise the ability to handle new information, and thus, the skill level of workers tends to reduce the costs of decentralization (see Bresnahan et al., 2001).

\footnotetext{
${ }^{3}$ Foreign firms operate against disadvantages such as inferior knowledge of local markets and tastes and inferior connections with local politicians and financial institutions. See e.g. Caves, 1996, Markusen 1995, and Bloningen and Slaughter, 2001.

${ }^{4}$ These assets are assumed to have a within-firm public good aspects to them, so they can be used across all firm's plants. The higher productivity of multinational parent can also result in higher wages of their foreign affiliates through international profit sharing. See Budd et al. (2005).
} 
There exits a growing body of literature, which examine empirically the relationship between foreign ownership and wages. Among the first ones is the study by Aitken et al. (1996), which examines the relationship between wages and foreign investments in Mexico, Venezuela and United States using data at industry-district-level. They found that a higher level of foreign ownership in an industry and location was associated with higher wages in all of these countries. Feliciano and Lipsey (1999) replicate the results of significant positive wage premium of foreign ownership for US using also industry-regional level data. Lipsey and Sjöholm (2001) use cross-section plant-level data from Indonesia manufacturing and find that foreign-owned firms pay higher wages even after controlling for plant characteristics, industry and location.

However, without establishment-level panel data it is impossible to examine, whether this finding is due to unobservable differences between foreignand domestically-owned plants, or whether the ownership status itself influences wages. Foreign-owned establishments might pay higher wages than domestically-owned establishment simply because foreign firms took over high-wage local establishments. Lipsey and Sjöholm. (2003) attempt to deal with the problem by using panel data on Indonesian establishments. They find strong increase in wages after foreign takeovers. The regression results without establishment- fixed effects show that foreign-owned establishments paid $29 \%$ more for blue-collar workers and $43 \%$ more white- collar workers than domestically- owned establishment with similar characteristics. If fixed effects were introduced the differentials are 10 and $21 \%$.

Conyon et al. (2002) examine the productivity- and wage- effects of foreign acquisitions in the UK using establishment-level panel data for the period 1988-94. They find that firms which are acquired by foreign companies pay in average $3,4 \%$ higher wages than domestic firms. However, when productivity is added in the control variables, this wage premium disappears. Almeida (2003) study the effect of foreign acquisition on domestic firms' wages and skill composition in Portugal using firm-level panel data for 1991-98. She finds that there exists an important selection effect as foreigners "cherry pick" the domestic firms that pay higher wages and employ 
more educated workers. Wages did however increase after the acquisition The increase was highest for highly educated workers (13\%), compared to that for medium-and low educated ones ( $5 \%$ and $3 \%$ respectively). Girma (2003) investigate the effects of the foreign takeovers on domestic skilled and unskilled wages using establishment-level panel data for UK. He finds that skilled workers, on average, experience a post-acquisition increase in the wage rate following an acquisition by a US firm, while no such effect is found following acquisition by other nationalities. Martins (2004) examine the effect of foreign ownership on wages using matched worker-establishment panel data for Portugal from 1991-99. Using OLS, he finds that foreign firms pay higher wages, even when firm and worker controls are added. However, the difference-in-differences analysis, both regression and matching, provide evidence that workers in firms that were acquired by foreign investors experience lower wage growth than the ones who were employed in firms that did not change their ownership status.

Studies which examine the effect of foreign acquisition on relative demand for different skill groups are much less numerous and results less clear. Bloningen and Slaughter (2001) examine the impact of inward FDI flows and foreign-affiliate presence on US skill upgrading using four-digit industry-level data for manufacturing from 1977 to 1994. They results suggest zero or negative correlation between increases in foreign-affiliate activity and skill upgrading in the US. Taylor and Driffield (2005) use similar framework with industry-level panel data to examine the role of foreign direct investment on wage inequality in UK. They find that FDI has significantly contributed to increase in the skilled wage bill share. Interestingly, the studies that use establishment level-panel data seem to find either negative or zero effect of foreign ownership on demand for highly educated workers. Lipsey and Sjöholm (2003) examine the changes in employment after takeovers and find a decrease in number of white-collar workers and a strong increase in blue-collar workers. Almeida (2003) finds no significant changes in the workforce's skill composition following a foreign acquisition for Portuguese establishments. 


\section{Statistical Framework}

The goal in this study is to examine the effect of foreign acquisition on the employment and wages of different skill groups in the acquired plants. We borrow the terminology from program evaluation literature. We define foreign acquisition as the "treatment", $D . \quad D=1$ denotes the treatment state, plant was acquired by a foreign firm, and $D=0$ denotes the nontreatment state, plant was not acquired by foreign firm. $Y(D)$ is the outcome associated with each state, e.g. wages and the employment share of different skill groups. Treatment group consist of plants that were acquired by foreign firm. Control group consist of plants that remained domestically-owned.

\subsection{Regression model}

We begin by estimating the effect of foreign acquisition on post-acquisition outcome using a linear regression model. The regression model can be describe as

$$
Y_{i, t}=\mathbf{X}_{i, t} \beta+\sum_{j=0}^{2} D_{i, t-j} \delta_{j+1}+\alpha_{i}+\zeta_{t}+\mu_{i, t}
$$

where $Y_{i, t}$, is the variable that describes the outcome of the plant $\mathrm{i}$ in period $\mathrm{t}$ (e.g. log. wages or employment share of different skill groups), $\mathbf{X}_{i, t}$ is a vector of observable plant, industry and local labor market characteristics, and $D_{i, t-j}$ is dummy variables indicating plant's foreign ownership status at $t-j, \alpha_{i}$ is the plant-fixed effect, and $\zeta_{t}$ is the year dummy. The interpretation of the estimated coefficients on the foreign ownership status, $\delta_{1}$ to $\delta_{3}$, is the following. Since the model includes plant-fixed effects, we are using the within-plants variation only, and thus the coefficient on the ownership variable can be interpreted as the effect of foreign acquisition. The effect of acquisition that happened within one year from the observation date is captured by the variable $D_{i, t}$, the effect of acquisition that happened two years ago is captured by the variable $D_{i, t-1}$, and the effect of acquisition that happened three years ago is captured by the variable $D_{i, t-2}$. Thus the 
estimated regression model gives an estimate for the foreign acquisition on outcome immediately after acquisition, 1-2 years after acquisition, and 2-3 years after acquisition. This allows us to see whether the possible changes in wages and employment of acquired plants happen instantly or after some adjustment period.

\subsection{Matching estimators}

Next we estimate the effect of foreign acquisition on employment and wages using different propensity score matching methods. The central idea in matching methods is that the bias, which arises due to differences in the characteristics of treatment and control group, is reduced when the comparison of outcomes is performed using treated and control subjects who are as similar as possible on their observable characteristics, $X$. The propensity score matching method (Rosenbaum and Rubin, 1983) proposes a way to summarize the vector of pre-treatment characteristics, $\mathrm{X}$, into single-index variable.

We begin by estimating the propensity score. In this study the propensity score is the conditional probability for a plant of being acquired by a foreign firm. The binary-choice model which describes the probability of foreign acquisition for plant $i$ is of the form

$$
D_{i t}=\left\{\begin{array}{cl}
1 & \text { if } \beta X_{i t-1}+\zeta_{t}+\gamma_{j}+\eta_{r}+\varepsilon_{i t}>0 \\
0 & \text { otherwise }
\end{array}\right.
$$

where $\mathrm{D}_{i t}$ is a binary variable which defines plant's acquisition status at year $t . D=1$, if a plant which was domestically-owned in year $t-1$ is foreign-owned at year $t$, and $D=0$ if which was domestically-owned in year $t-1$ is not foreign-owned at year $t^{5} . X_{i t-1}$ is a vector of factors that affect plant's probability of being acquired by a foreign firm. Since the acquisition happens between $t$ and $t-1$ we use the characteristics from period $t-1$ as the pre-treatment variables. In order to control for unobservable common

\footnotetext{
${ }^{5}$ The sample used in matching analysis consists only of plants that were domesticallyowned in the first observation years, i.e. before the period $t$.
} 
industry, region and time effects the model also includes full set of controls for fixed industry $\left(\gamma_{j}\right)$, region $\left(\eta_{r}\right)$, and time-effects $\left(\zeta_{t}\right)$.

The next step is to use the estimated propensity score in order to estimate the average effect of foreign acquisition ${ }^{6}$. The idea is to use the outcome of the non-treated observations (plants that remained domestically-owned) with similar propensity score to proxy, what would have happened to treated observations (acquired plants) in the non-treatment situation. The Average effect of Treatment on Treated (ATT) for all type of cross section -matching estimators can be written as

$$
\widehat{A T T}(S)=\sum_{i \in T \cap S_{P}} \frac{1}{N^{T}}\left[Y(1)_{i}-\sum_{j \in C \cap S_{P}} i_{i j} \omega_{i j} Y(0)_{j}\right]
$$

where $Y(1)_{i}$ is the treatment outcome for unit (plant) i, $Y(0)_{j}$ is the nontreatment outcome for unit $\mathrm{j}$ (comparison group outcome), $N_{T}$ is the number of units in treatment group, $T$, and $C$ denotes the set of control units, $S_{P}$ denotes the region of common support and $\omega_{i j}$ is the weight that is used to match control units with each treatment unit.

Matching methods rely crucially on the assumption that there are no unobservable factors which affects both the selection into treatment and the outcome. In order to control for the possible bias that is due to selection on unobservables we compute the average effect of treatment on treated using the difference-in-differences matching estimator (Heckman et al., 1997). This estimator compares the difference in the outcome before and after the treatment of treated units with the difference in the outcome of the nontreated units in the same period. It allows for the existence of unobserved time-invariant factors that affect the selection. The formula for ATT can

\footnotetext{
${ }^{6}$ This is after testing that the balancing property holds, i.e. whether observations with the same propensity score have the same distribution of observable characteristics independently of treatment status. We use algoritm silimar to Ichino and Becker (2003).
} 
calculated as

$$
\widehat{A T T}(S)=\sum_{i \in T} \frac{1}{N^{T}}\left[\left(Y(1)_{i t}-Y(0)_{i t-1}\right)-\sum_{j \in C}{ }_{i j} \omega_{i j}\left(Y(0)_{j t}-Y(0)_{j t-1}\right)\right]
$$

where $t$ is the post acquisition time period and $t-1$ is the pre-acquisition time period.

\section{Data}

\subsection{Description of the data sources}

The main data source in this study is the Plant Level Employment Statistics Data on Average Characteristics (PESA). It is a longitudinal data on Finnish establishments, with linked information on worker characteristics aggregated on the establishment level by skill groups. The linked worker characteristics-establishment data are constructed by linking data on workers in the Employment Statistics database of Statistics Finland to data on plants of Business Registers and Industrial Statistics. The data set covers all the private sector establishments (except traffic and construction) with more than two workers. The time period is 1988-2001. The number of establishments is around 50000 each year. Employees are aggregated into 70 different skill groups by education, age and sex (see table 1). The data contain information on aggregate worker characteristics for each skill

group, such as number of people, average monthly wage, general working experience, tenure and education. The data set does not have any specific information on establishment characteristics. However, each enterprise and its plant, has a unique identification code, which can be used to match additional information from other registers on the database.

Another major data source used in the analysis is the Longitudinal Data on Plants in Manufacturing (LDPM), which is constructed especially for research purposes from Annual Industry Statistics. For the period 19741994 it covers all manufacturing sector plants with more than 5 workers and 
for the period 1995-2001 it covers the plants of firms employing at least 20 persons. The number of plants varies between 9000 and 3000 each year.

For the purpose of our analysis we form data set by linking the PESA data set with LDPM data. The linked data set covers manufacturing plants from the years 1988-2001. As the LDPM data set for the years 1995-2001 consists only the plants of firms that employ at least 20 persons, the number of observations per year is considerably smaller after 1994. In order to have consistent data set we thus restrict the sample to cover only plants of the firms which employ at least 20 workers. This sample consists 46290 plantyear observations.

The variables describing the employee characteristics are obtained from the PESA data set. All this variables are skill-group averages in the establishment. The main variables describing employee characteristics are: monthly wage, employment, wage bill share, tenure, age, and education. Employment describes the number of workers in a skill group working in an establishment during the last week of the year. The average monthly wage is calculated as the skill group average of the average monthly wages of individual workers who were employed in the establishment during the last week of the year. The average monthly wage for each individual employed is calculated by dividing the wage income by months of employment. The monthly wage bill for each skill group is formed by multiplying the average monthly wage of the skill group by the number of workers in the skill group employed in the establishment during the last week of the year. Age is the average age of workers in the skill group employed in the establishment during the last week of the year. Average education is calculated as the average of the years of schooling for each skill group, and average tenure is calculated as the average of the months of tenure in the skill group.

Variables describing the plant characteristics, including the foreign ownership status, are from the LDPM data set. The variable defining foreign ownership status is created using the information on the share of foreign owners of the plant. An establishment is labeled as foreign-owned if the share of foreign ownership is at least $20 \%^{7}$. The other main establishment

\footnotetext{
${ }^{7}$ We have two main reasons to us the $20 \%$ threshold. First, Most of the previous
} 
characteristics used in the analysis are sales, real value added, real capital stock and exports.

We use two different samples in this analysis. In the basic regressions (described in section 3.1.) we use all the observations from the matched PESALDPM data for which we have information on the characteristics needed in regressions. These include the information on plant's foreign ownership status in the current year, and in the two previous observation years. This sample consists of plants from the years 1990-2001. In the matching analysis we use different sample. The construction of this sample is described below.

\subsection{Matching Sample Construction}

The sample of plants that was used in the matching analysis in this article is constructed as follows. From the overall data base, we first identify plants, which we can observe in the data set at least two consecutive years before the current year, and which were domestically-owned in all the years before the current year. We label the current year as the period 1. The previous years are labeled as 0 and -1 , and the following years 2 and 3 . We divide these plants into treatment and control groups. The treatment group is the plants which were acquired by foreign firms in the period between 0 and 1 . The comparison group is the plants which remained domesticallyowned until the period 3. We remove from the sample all the plants that do not have information on all the observational characteristics that are used in matching and regressions. Since in matching we are using information from two years before the acquisition, and examine the outcome until the third year after acquisition, we can use only information on plants that we can observe for at least five consecutive years. The final matching sample consists of 14441 observations. It covers the years 1990-1999. The number of foreign-acquired plants is 284 . The number of observations in control group is 14157 .

studies label establishment as foreign-owned if $10 \%$ or $20 \%$ of its ownership is foreign (e.g. Bloningen and Slaughter, 2001, Aitken et al., 1996, Almeida, 2003). Second, most $(88 \%$.) of the plants in our data with at least $20 \%$ foreign ownership have more than $50 \%$ foreign ownership. We use $50 \%$ threshold for robustness checking. 


\section{$5 \quad$ Results}

\subsection{Descriptive Evidence}

Table 2 reports the share of foreign-owned plants in the LDPM/PESA in 1989-2001 and the share of workers employed in foreign-owned plants in the data set. The share of foreign-owned plants has increased significantly during the period in Finland. While in the late 1980's only around $4 \%$ of plants were foreign-owned, in 2001 the share is 19\%. Table 1 also shows how much of this increase is due to takeovers of domestic plants by foreign firms (acquisitions), and how much due to new plants started-up by foreign firms. Most of the increase in the number of foreign-owned plants is due to acquisitions. The lower panel of table 2 shows that the increase in the share in the employment of foreign-owned plants has been even more rapid than the increase in the number of plants, from 5 to $22 \%$. Acquisitions contribute for most of the increase.

Before presenting the matching and regression results it is interesting to see whether there are significant differences between wages and other observable characteristics of foreign-owned and domestically-owned plants in Finnish manufacturing. Table 3 reports the mean values of the main characteristics for the foreign-owned and domestically-owned plants in the sample. The results imply that foreign-owned plants pay higher wages for both highly and low educated workers than domestically-owned plants ${ }^{8}$. But they also have other observable characteristics which can explain higher wages: they are bigger, older, employ more skilled workers, are more likely to export, or to have $\mathrm{R} \& \mathrm{D}$ activity. The average employee characteristics of these plants vary as well. Foreign-owned plants employ workers who are older, have more years of schooling, and who have a longer tenure.

Evidently, this does not tell us whether the foreign-owned plants were different from the domestic-owned plants already before the acquisition happened. Table 4 describes the differences in the observable characteristics of

\footnotetext{
8"Low educated" refers to people with basic, vocational and lower secondary education. "Highly educated" refers to people with educational qualifications from colleges, polytechnics or universities.
} 
acquired and non-acquired plants from the pre-and post-acquisition periods. The sample consists of plants for which we can find information on observable characteristics 2 years before the possible acquisition and 3 years after the acquisition. The pre-acquisition periods are marked as $-1,0$, and post-acquisition periods, 1,2 , and 3 . The acquisition happens between 0 and 1. The result shows that the plants which were acquired by foreign firms had characteristics which are associated with higher wages even before the acquisition happened. They are bigger, have higher sales, they have larger share of exports from they total sales, they employ workers that are older, have more schooling and longer tenure. In addition they employ less females and are more capital-intensive and productive. The difference in the characteristics remains after acquisition.

Next rows in table 4 report the differences in the four different outcome measures from the two periods preceding acquisition until the third year after acquisition. The outcome measures are: 1) logarithm of average wage of low educated workers in the plant, 2) logarithm of average wage of highly educated workers in the plant, 3) share of highly educated workers in employment, and 4) share of highly educated workers in total wage bill. The result show that foreign acquired plants pay higher wages for both highly and low educated workers even before the acquisition occurs. The difference in the wages increases after acquisition and continues increasing until the third year after acquisition. The acquired plants also employ more highly educated workers before they become foreign-owned. The difference remains after acquisition, but diminishes in time.

\subsection{Regression results for the whole sample}

As shown in table 3, foreign-owned plants in Finland pay higher wages than domestically-owned plants, but also have other characteristics that are related to higher wages. We now ask whether foreign-owned plants pay higher wages given these characteristics, industry, and location. We begin our analysis by running an OLS regression on wages of different skill groups. Results are reported in table 5 . The first column (model 1) is an OLS speci- 
fication, where we control for various plant-, and worker-characteristics ${ }^{9}$. In addition the specification includes controls for common time-, region-, and two-digit-industry- effects. Consistently with previous studies, the pooled OLS result show that foreign-owned plants pay higher wages even after controlling for the plant-, and worker-characteristics, and for industry, region and common time effects. The foreign wage premium is higher for highly educated workers than for less educated workers: 0,052 and 0,036 respectively.

Regression analysis with rich set of controls for plant- and worker- characteristics within regions and within industries is likely to eliminate some of the bias that arises from the result of the possible selection of high-wage establishments for acquisition by foreign-firms. However, there may be some unmeasured characteristics that are associated with both high wages and foreign ownership that bias the results. In order to control for these characteristics model 2 includes plant-specific fixed effects. When fixed-effects are introduced the foreign-ownership wage premium is reduced to 0,013 for low educated workers and to 0,015 for highly educated workers.

The last columns in table 5 report the results for a specification which includes plant fixed-effects and foreign ownership dummies for current period, and for two previous periods. This means that plant's foreign-ownership status is allowed to affect wages in the current year, and also in the two years after the change in ownership (acquisition) has happened. The results indicate that the effect of foreign ownership grows in time. For low educated workers the effect of foreign ownership is strongest in the second year after acquisition, and for the highly educated workers on the third year.

Table 6 reports the results of the effect of foreign ownership on the share of highly educated workers in plant's employment and total wage bill. The results of the different specification, with or without plant fixed effects, indicate that foreign-owned plants employ slightly more highly educated workers than domestically-owned plants. However, the results from the third specification suggests that this difference is not likely to remain after acquisition.

\footnotetext{
${ }^{9}$ The worker characteristics are skill-group averages at plant level.
} 


\subsection{Results for the matching sample}

The next important issue is whether the effect of foreign acquisition is heterogeneous with respect to observational characteristics. If this is the case, we must make sure a suitable comparison group exits. One way to address this problem is to use propensity score matching methods. The crucial requirement in matching is, that we take into account all the possible observational characteristics that might affect both the probability of being acquired by foreign firm and the outcome. In order to ensure this we will use rich set of worker, plant and region characteristics from different preacquisition periods. Since we want to examine how the effect of foreign acquisition evaluates in time, we need to have information of the outcome variables from 3 post-acquisition periods. These requirements mean that the sample that can be used in matching is considerable smaller, as described in section 4.2. In this section we report the regression and matching results for this matching sample.

The propensity score, the conditional probability of being acquired by foreign firm, is estimated by parametric probit model. The results of the probit estimations are presented in table 7 . The dependent variable gets value one if the plant was acquired by foreign firm between periods 0 and 1. The variables which are use to predict the probability of being acquired by a foreign firm, i.e. pre-treatment variables, are from the pre-acquisition periods 0 and -1 . The pre-acquisition characteristics from period 0 include plant size (number of employees), squared plant size, logarithm of total sales of the plant, export/sales ratio and its square, share of exporting plants in two-digit industry, and share of foreign-owned plants in the two-digit industry, and total sales in the region (to control for the size of the market). The information from plant average characteristics are from period -1 . These include the average years of schooling of plant's employees, average age of plant's employees, average tenure of plant's employees and the square of average tenure ${ }^{10}$. In addition the specification includes two-digit region

\footnotetext{
${ }^{10} \_0$ in end of the variable refers to period just before acquisition $(0)$, and _ 1 to period 1-2 years before acquisition $(-1)$.
} 
controls, one-digit industry controls and full set of time dummies.

The estimation results indicate that plant size has a negative effect on the probability of being acquired by a foreign firm, once plant's total sales in the period are taken into account. Plant's sales have a significant positive impact on the acquisition probability. If the sales variable is excluded from the regression the plant size variable gets highly positive and significant coefficient. Plant's export/sales ratio is positively related to the acquisition probability. However, the share of exporting plants in an industry is negatively related to acquisition probability once plant's own exports are taken into account. This might indicate that these industries have higher transport costs, and firms are more likely to acquire plants directly from these industries rather than decide to trade. The share of foreign-owned plants in industry predicts positively the likelihood of being acquired. This is expected, since this variable might capture many unobservable industryspecific factors that lead foreign firms to acquire plants from these industries. The variable describing sales in the region, i.e. market size, gets positive but insignificant coefficient. Next we look at the effect of plant's average employee characteristics on the acquisition probability. Plants that pay high wages in period -1 are more likely to end up being foreign-owned between 0 and 1. Also plants with highly educated and high tenure workers seem to be more attractive to foreign firms. Workers' average age decreases the probability of foreign acquisition.

Next we estimate the effect of foreign acquisition using the estimated propensity score. The first rows in table 8 show the effect of acquisition on the average wages of the low educated workers in a plant in the period just following the acquisition, $t=1$. The first columns show the results from cross-section matching. The dependent variable is the level of the wages in the period. As a benchmark we report a results from a regression in the first column, where the outcome variable is regressed on all the X's that are used to estimate the propensity score, and on a dummy which explains whether the plant is foreign-owned or not. We impose the common support condition, i.e. include only the observations, which have the propensity score within the common support region. The estimated coefficient on foreign-acquisition 
is negative -0.012 and not significantly different from zero.

The next two columns present the estimated effects of foreign acquisition on average wages using different matching estimators. The nearest-neighbor estimator with replacement gives slightly stronger negative effect (-0.024), but it is still not statistically significantly different from zero. Next column reports the results from Kernel matching. While nearest neighbor matching uses only those control group observations that are closest to treated units, Kernel matching uses all the control group observations, but weights each observation according to its distance from the treated unit. Kernel matching estimator shows strong positive effect $(0.056)^{11}$.

The last three columns report the results from difference-in-differences regression- and matching estimations. The dependent variable is the difference of the wages between the pre-acquisition period (0) and the different post-acquisition time periods. The fourth column shows the result from regression, where the change in the logarithm of monthly wages of low educated workers from 0 to 1 is regressed on foreign-ownership dummy and on all the controls that were used to estimate the propensity score. The next columns report the results from nearest-neigbour and kernel difference-indifferences matching. The results show that foreign acquisition does not have any significant effect on average wages of low educated workers. The estimated effect varies from -0.002 to 0.001 . There seems to be much less differences between regression, kernel and nearest neighbor estimates than with cross-section matching estimators. This indicates that the cross-section matching assumptions (conditional independence assumption) might not hold for our sample, and once the permanent differences between the plants are taken into account by difference-in-differences matching or regression, the result seem to be more robust.

\footnotetext{
${ }^{11}$ We use here Gaussian kernel and the bandwidth 0.06 . We also tried other bandwidths, such as 0.01 and 0.02 . With smaller bandwidth choices the kernel estimates became smaller and less significant and thus, more closer to the nearest neighbour estimates. This makes sense, since the smaller the bandwidth choice, more weight is put on the control group observations which have propensity score that is closest to the treated units. The fact that the bandwidth choice makes a difference might indicate that the cross-section matching assumptions do not hold. The bandwidth choice did not have significant effect to the difference-in-differences matching estimator.
} 
The changes in employment and wages that are caused by foreign acquisition might not happen instantly. Next rows in table 8 report the results on the effect on the wages of low educated workers in the second year following the acquisition. The cross-section matching results are still quite unrobust, although clearly more positive than in the first year. The difference-indifferences matching and regression indicate that the foreign acquisition has a positive and highly significant effect on the wages of low educated workers in the second year after acquisition. The magnitude of the effect varies between 0,042-0,040. When looking at the wages at the third year after acquisition the result remain robust. Low educated workers in plants which were acquired by foreign firms earn significantly more in the third year after acquisition than workers in plants that remained domestic during that time. The difference in the wages has, however, decreased a bit from the previous year.

Table 9 reports the results of the effect of foreign acquisition for highly educated workers. Both the matching and regression results indicate that acquisition does not have a significant effect on the wages in the year immediately after acquisition. As in previous table, the difference-in differences results are more robust to different estimation methods. In the second year, the effect of foreign acquisition is significant and positive, varying from 0.021 to 0.079 . In the third year after acquisition the effect seems to be even stronger, varying between 0.014-0.084. Thus, it seems that acquisition raises the wages of highly educated workers, but this raise is not immediate.

Table 10 shows the results of the effect of the acquisition on the share of highly educated workers in plant's employment. The result indicate that foreign acquisition does not have any effect on the skill composition of plant's workforce in the first year after acquisition. In the following years, the difference-in-differences results indicate significant and negative effect of the foreign acquisition. Table 11 replicates the results using the share of highly educated workers in total wage bill as the outcome variable. The result indicate again no significant effect on the first year, but negative effect on the second and third year. The magnitude of the effect is slightly lower than for the employment share, which might indicate that the relative increase in 
high skilled wages compensates the drop in total employment share.

Finally we look whether there is even more heterogeneity in wage effects according to the educational level of workers. Table 12 reports the differencein-differences matching results for the effect of foreign acquisition on wages of four different educational categories: basic, vocational, lower university, and higher university. The results again indicate that the magnitude of the effect depends on worker's educational level. There is a clear increase in the magnitude of the effect by the level of schooling of the workers.

\section{Conclusions}

This paper examines the effect of foreign acquisition on wages and employment of different skill groups using panel data on Finnish establishments for the years 1988-2001. Exploiting the availability of rich set of pre-acquisition controls, we use various regression and propensity score matching methods, including difference-in-differences matching. Both regression and matching results indicate that foreign acquisition has a positive effect on wages. The magnitude of this effect increases with the level of schooling of the workers. The wage increase is not immediate, but happens within 1-3 years from the acquisition. This can be due to various reasons. First, foreign firms do more on-the-job-training, and thus the wage growth in foreign-owned firms is higher. This implies that wages in plants that are acquired by foreign-owned firms do not raise immediately, but within some years after acquisition. The finding that wages seem to rise more rapidly for highly educated workers might indicate bigger returns to training for highly educated workers ${ }^{12}$. Second reason for the fact that wages do not rise immediately, is that acquisition can involve organizational changes within plant, and the implementation of new work practises might take time. Third, the changes in average wages can be associated with changes of employment composition of plant's workforce. Since there are adjustment costs associated with these employment changes, they are not likely to be immediate. Finally, due to possible measurement problems, the exact timing of the acquisition might

\footnotetext{
${ }^{12}$ See e.g. see Altonji and Spletzer (1991).
} 
be uncertain. The result on employment effect indicate that acquired plants reduce, although slightly and slowly, the share of highly educated workers in their employment. This finding, although quite surprising, is in line with findings from the few earlier studies that have examined the changes in skill mix after acquisition (Lipsey and Sjöholm, 2003, Almeida, 2003).

\section{References}

[1] Aitken, Brian J., Ann E. Harrison and Robert E. Lipsey (1996): Wages and foreign ownership: A comparative study of Mexico, Venezuela, and the United States, Journal of International Economics, 3-4, 345-371.

[2] Almeida, Rita (2003): The Effects of Foreign Owned Firms on the Labour Market, IZA Discussion Paper 785.

[3] Altonji, Joseph G., and James R. Spletzer (1991): Worker Characteristics, Job Characteristics, and the Receipt of on-the-Job Training, Industrial and Labour Relations Review, 45 (1), 58-79.

[4] Becker, Sascha O. and Andrea Ichino (2002): Estimation of average treatment effects based on propensity scores, Stata Journal, 2, 358-377.

[5] Blonigen, Bruce A., and Matthew J. Slaughter (2001), Foreign Affiliate Activity and U.S. Skill Upgrading, Review of Economics and Statistics, $83(2), 362-376$

[6] Bresnahan, Timothy, Erik Brynjolfsson and Lorin M. Hitt, (2002), Information Technology, Workplace Organization, and the Demand for Skilled Labor: Firm Level Evidence, Quarterly Journal of Economics, 117, 339-376.

[7] Budd, John W., Jozef Konings, and Matthew J. Slaughter (2005), Wages and International Rent Sharing in Multinational Firms, Review of Economics and Statistics, 87(1), 73-84

[8] Caves, Richard (1996): Multinational Enterprises and Economic Analysis, Cambridge University Press, Cambridge. 
[9] Conyon, Martin J., Sourafel Girma, Steve Thompson and Peter W. Wrigh (2002): The Impact of Foreign Acquisition on Wages and Productivity in the UK, Journal of Industrial Economics, 50(1), 85-102

[10] Feliciano, Zadia and Robert E. Lipsey (1999): Foreign Ownership and Wages in the United States, 1987-1992, NBER Working Paper 6923.

[11] Fosfuri, Andrea, Massimo Motta and Thomas Ronde (2001): Foreign Direct Investment and Spillovers Through Workers' Mobility, Journal of International Economics, 53. 205-222.

[12] Girma, Sourafel (2003): Evaluating the Causal Effects of Foreign Acquisition on Domestic Skilled and Unskilled Wages, IZA Discussion Paper 903.

[13] Görg, Holger (2002): Why Do Foreign-Owned Firms Pay More? The Role of On-the-Job Training, IZA Discussion Paper No. 590.

[14] Heckman, James J., Hidehico Ichimura and Petra Todd (1997): Matching as An Economic Evaluation Estimator: Evidence from a Job Training Program, Review of Economic Studies, 64 (4), 605-654.

[15] Honkapohja Seppo, and Erkki Koskela (1999): The economic crisis of the 1990s in Finland, Economic Policy, 14, 29, 399-436

[16] Lipsey, Robert E., and Frederik Sjöholm (2001): Foreign Direct Investment and Wages in Indonesian Manufacturing, NBER Working Paper No. 8299

[17] Lipsey, Robert E., and Frederik Sjöholm (2003): Foreign Firms and Indonesian Manufacturing Wages: An Analysis with Panel Data, NBER Working Paper No. 9417.

[18] Markusen, James R. (1995), The Boundaries of Multinational Enterprises and the Theory of International Trade, Journal of Economic Perspectives, 9, 169-189. 
[19] Martins, Pedro S. (2004): Do Foreign Firms Really Pay Higher Wages? Evidence from Different Estimators, University of St. Andrews, IZA Discussion Paper No. 1388 .

[20] Rosenbaum, P. and D. Rubin (1983): The Central Role of Propensity Score in Observational Studies for Causal Effects, Biometrica, 70, 41-55.

[21] Taylor, Karl, and Nigel Driffield (2005): Wage Inequality and the Role of Multinationals: Evidence from UK Panel Data, Labour Economics, Vol. 12, Issue 2, 223-249 
Figure 1 Foreign direct investment in Finland in 1991-2001, stock of investment at the end of the year, EUR million

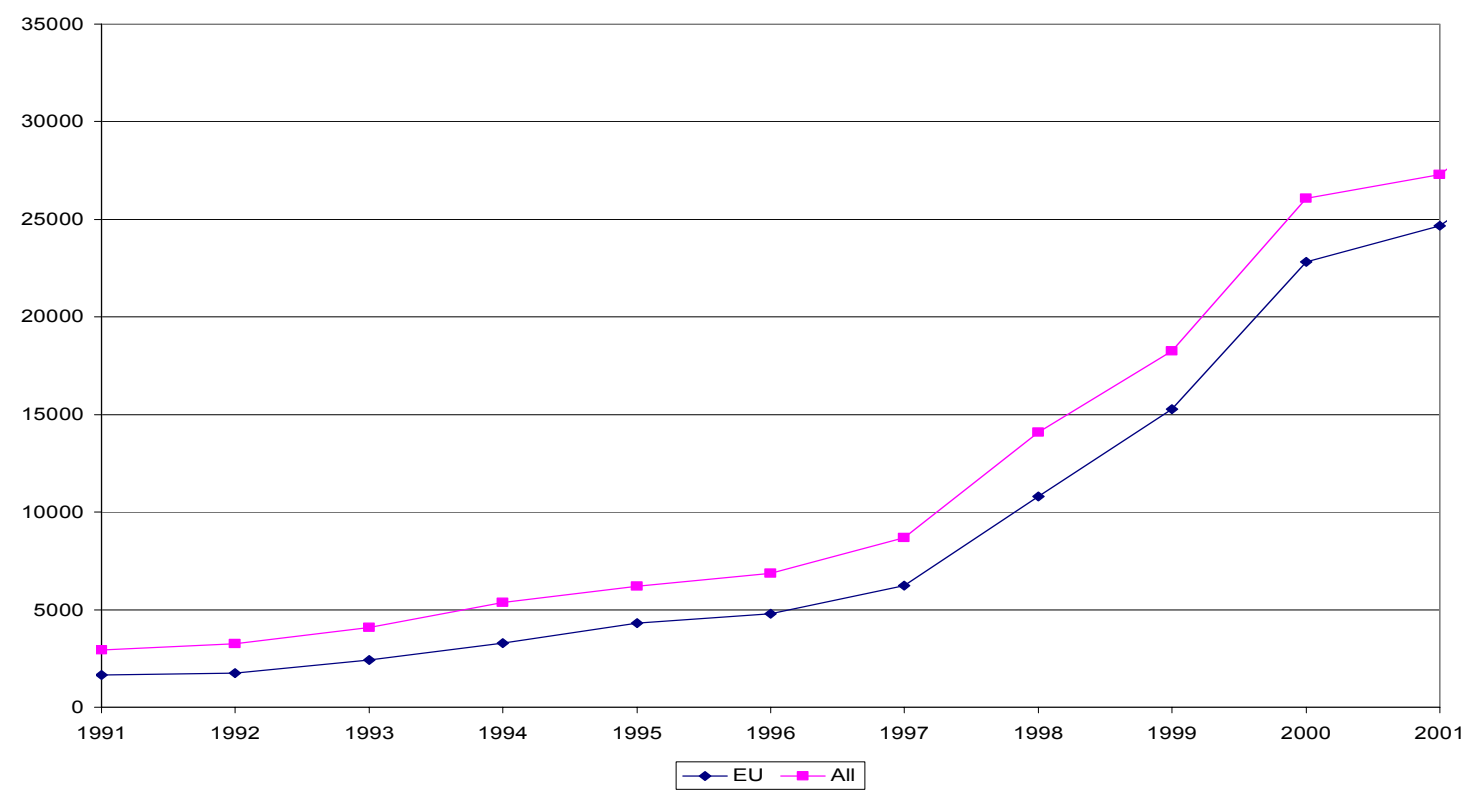

Source: Bank of Finland

Table 1 Disaggregation of establishment's work force in PESA data

\begin{tabular}{|l|l|l|l|l|l|l|l|l|l|l|}
\hline Age & $15-24$ & $25-34$ & $35-44$ & $45-54$ & \multicolumn{2}{l|}{$55-64$} \\
\hline Sex & $\mathrm{m}$ & $\mathrm{f}$ & $\mathrm{m}$ & $\mathrm{f}$ & $\mathrm{m}$ & $\mathrm{f}$ & $\mathrm{m}$ & $\mathrm{f}$ & $\mathrm{m}$ & $\mathrm{f}$ \\
\hline Educational level: & & & & & & & & & & \\
\hline 1. basic & 1 & 2 & 3 & 4 & 5 & 6 & 7 & 8 & 9 & 10 \\
2.vocational / technical & 11 & 12 & 13 & 14 & 15 & 16 & 17 & 18 & 19 & 20 \\
3. vocational/ other & 21 & 22 & 23 & 24 & 25 & 26 & 27 & 28 & 29 & 30 \\
4. low. univ./technical & 31 & 32 & 33 & 34 & 35 & 36 & 37 & 38 & 39 & 40 \\
5. low. univ./ other & 41 & 42 & 43 & 44 & 45 & 46 & 47 & 48 & 49 & 50 \\
6. higher univ./technical & 51 & 52 & 53 & 54 & 55 & 56 & 57 & 58 & 59 & 60 \\
7. higher univ./other & 61 & 62 & 63 & 64 & 65 & 66 & 67 & 68 & 69 & 70 \\
\hline
\end{tabular}


Table 2 Number and employment of foreign-owned plants in the sample of Finnish manufacturing plants in 1989-2001

\begin{tabular}{|c|c|c|c|c|c|c|c|c|c|}
\hline \multicolumn{10}{|c|}{ Number of plants } \\
\hline \multirow[b]{3}{*}{ Year } & \multirow{3}{*}{$\begin{array}{c}\text { All plants } \\
\text { All } \\
\text { Freq. }\end{array}$} & \multicolumn{8}{|c|}{ Foreign-owned plants } \\
\hline & & \multicolumn{2}{|c|}{ All foreign owned } & \multicolumn{2}{|c|}{ Foreign owned at $\mathrm{t}-1$} & \multicolumn{2}{|c|}{ New plants } & \multicolumn{2}{|c|}{ Acquired plants } \\
\hline & & Freq. & $\%$ & Freq. & $\%$ & Freq. & $\%$ & Freq. & $\%$ \\
\hline 1989 & 3775 & 154 & 4.08 & 114 & 3.02 & 32 & 0.85 & 8 & 0.21 \\
\hline 1990 & 3941 & 173 & 4.39 & 126 & 3.20 & 27 & 0.69 & 20 & 0.51 \\
\hline 1991 & 3758 & 174 & 4.63 & 138 & 3.67 & 23 & 0.61 & 13 & 0.35 \\
\hline 1992 & 3390 & 148 & 4.37 & 120 & 3.54 & 13 & 0.38 & 15 & 0.44 \\
\hline 1993 & 3263 & 290 & 8.89 & 116 & 3.56 & 52 & 1.59 & 122 & 3.74 \\
\hline 1994 & 3364 & 323 & 9.60 & 246 & 7.31 & 33 & 0.98 & 44 & 1.31 \\
\hline 1995 & 2951 & 294 & 9.96 & 261 & 8.84 & 20 & 0.68 & 13 & 0.44 \\
\hline 1996 & 2994 & 298 & 9.95 & 261 & 8.72 & 18 & 0.60 & 19 & 0.63 \\
\hline 1997 & 2966 & 410 & 13.82 & 261 & 8.80 & 23 & 0.78 & 126 & 4.25 \\
\hline 1998 & 3036 & 467 & 15.38 & 298 & 9.82 & 47 & 1.55 & 122 & 4.02 \\
\hline 1999 & 3000 & 492 & 16.40 & 342 & 11.40 & 29 & 0.97 & 121 & 4.03 \\
\hline 2000 & 3016 & 469 & 15.55 & 395 & 13.10 & 47 & 1.56 & 27 & 0.90 \\
\hline 2001 & 3028 & 585 & 19.32 & 412 & 13.61 & 65 & 2.15 & 108 & 3.57 \\
\hline \multicolumn{10}{|c|}{ Employment } \\
\hline & All plants & \multicolumn{8}{|c|}{ Foreign-owned plants } \\
\hline & All & \multicolumn{2}{|c|}{ All foreign owned } & \multicolumn{2}{|c|}{ Foreign owned at $t-1$} & \multicolumn{2}{|c|}{ New plants } & \multicolumn{2}{|c|}{ Acquired plants } \\
\hline Year & Freq. & Freq. & $\%$ & Freq. & $\%$ & Freq. & $\%$ & Freq. & $\%$ \\
\hline 1989 & 299516 & 14020 & 4.68 & 10398 & 3.47 & 3400 & 1.14 & 222 & 0.07 \\
\hline 1990 & 313516 & 17708 & 5.65 & 12456 & 3.97 & 1492 & 0.48 & 3757 & 1.20 \\
\hline 1991 & 274683 & 13823 & 5.03 & 11533 & 4.20 & 599 & 0.22 & 1691 & 0.62 \\
\hline 1992 & 255073 & 10597 & 4.15 & 8631 & 3.38 & 577 & 0.23 & 1389 & 0.54 \\
\hline 1993 & 244972 & 14982 & 6.12 & 9156 & 3.74 & 1347 & 0.55 & 4476 & 1.83 \\
\hline 1994 & 257383 & 19720 & 7.66 & 14527 & 5.64 & 1524 & 0.59 & 3669 & 1.43 \\
\hline 1995 & 253064 & 19818 & 7.83 & 17783 & 7.03 & 554 & 0.22 & 1481 & 0.59 \\
\hline 1996 & 255878 & 21063 & 8.23 & 16907 & 6.61 & 1036 & 0.40 & 3120 & 1.22 \\
\hline 1997 & 269185 & 43647 & 16.21 & 21006 & 7.80 & 994 & 0.37 & 21647 & 8.04 \\
\hline 1998 & 275450 & 40728 & 14.79 & 27556 & 10.00 & 2051 & 0.74 & 11118 & 4.04 \\
\hline 1999 & 257901 & 49861 & 19.33 & 32097 & 12.45 & 1496 & 0.58 & 16268 & 6.31 \\
\hline 2000 & 263745 & 50370 & 19.10 & 44338 & 16.81 & 2068 & 0.78 & 3964 & 1.50 \\
\hline 2001 & 259915 & 58954 & 22.68 & 47848 & 18.41 & 3377 & 1.30 & 7729 & 2.97 \\
\hline
\end{tabular}

Table 3 Descriptive Statistics for the sample

\begin{tabular}{lcccc} 
Variable & Domestic-owned & \multicolumn{3}{c}{ Foreign-owned } \\
\hline Plant size & Obs & Mean & Obs & Mean \\
Plant age & 37297 & 90.37 & 3866 & 101.91 \\
Wage & 17994 & 9.33 & 1989 & 9.82 \\
Wage low ed. & 36998 & 11928 & 3838 & 13617 \\
Wage highly ed. & 36806 & 10926 & 3796 & 12125 \\
Av. Schooling & 34666 & 15093 & 3587 & 17076 \\
Av. Tenure & 36998 & 11.56 & 3838 & 11.81 \\
Av. Age of employees & 36998 & 10.53 & 3838 & 11.70 \\
Share of highly educated & 36998 & 39.63 & 3838 & 40.50 \\
Share of high.ed. in wage bill & 36998 & 0.21 & 3838 & 0.26 \\
Share of female & 36998 & 0.26 & 3838 & 0.32 \\
Value Added & 36998 & 0.31 & 3838 & 0.29 \\
Export share & 37248 & 654483 & 3858 & 738789 \\
R\&D unit & 35085 & 0.20 & 3660 & 0.27 \\
\hline
\end{tabular}


Table 4 Difference in the characteristics of acquired and non-acquired plants before and after acquisition in matching sample

\begin{tabular}{|c|c|c|c|c|c|c|}
\hline \multirow[b]{2}{*}{ Variable } & \multicolumn{2}{|c|}{ Acquired plants } & \multicolumn{2}{|c|}{ Non-acquired plants } & \multicolumn{2}{|c|}{ Difference } \\
\hline & Obs & Mean & Obs & Mean & & $\%$ \\
\hline \multicolumn{7}{|c|}{ Pre-acquisition characteristics (from $\mathrm{t}=0$ ) } \\
\hline Size_0 & 284 & 153.18 & 14157 & 115.40 & 37.79 & 24.67 \\
\hline Log(sales)_0 & 284 & 9.50 & 14157 & 8.91 & 0.59 & 6.26 \\
\hline $\mathrm{K} / \mathrm{L} \_0$ & 259 & 216.67 & 12682 & 145.09 & 71.57 & 33.03 \\
\hline $\mathrm{Y} / \mathrm{L} \_0$ & 284 & 19845 & 14110 & 10650 & 9196 & 46.34 \\
\hline Export/sales_0 & 284 & 0.33 & 14157 & 0.24 & 0.09 & 28.33 \\
\hline Av. Age_0 & 284 & 40.43 & 14112 & 39.64 & 0.79 & 1.95 \\
\hline Av. school_0 & 284 & 11.74 & 14112 & 11.46 & 0.28 & 2.37 \\
\hline Av. tenure_0 & 284 & 12.42 & 14112 & 11.15 & 1.27 & 10.20 \\
\hline Female-share 0 & 284 & 0.31 & 14112 & 0.31 & -0.01 & -2.86 \\
\hline \multicolumn{7}{|c|}{ Post-acquisition characteristics (from $\mathrm{t}=1$ ) } \\
\hline Size & 284 & 149.58 & 14157 & 115.46 & 34.12 & 22.81 \\
\hline Log(sales) & 284 & 9.56 & 14086 & 8.94 & 0.62 & 6.44 \\
\hline $\mathrm{K} / \mathrm{L}$ & 260 & 152.60 & 12707 & 142.48 & 10.12 & 6.63 \\
\hline $\mathrm{Y} / \mathrm{L}$ & 284 & 22522 & 14150 & 10856 & 11666 & 51.80 \\
\hline Export/sales & 284 & 0.32 & 14086 & 0.23 & 0.09 & 26.63 \\
\hline Av. Age & 284 & 40.39 & 14157 & 40.01 & 0.37 & 0.92 \\
\hline Av. School & 284 & 11.73 & 14157 & 11.50 & 0.23 & 1.94 \\
\hline Av. tenure & 284 & 12.38 & 14157 & 11.47 & 0.90 & 7.29 \\
\hline Female-share & 284 & 0.30 & 14157 & 0.31 & -0.02 & -5.62 \\
\hline \multicolumn{7}{|c|}{ Wages of low educated from -1 to +3} \\
\hline Log. Wage low ed._1 & 282 & 9.33 & 14127 & 9.25 & 0.08 & 0.89 \\
\hline Log. Wage low ed._0 & 280 & 9.34 & 14083 & 9.27 & 0.07 & 0.78 \\
\hline Log. Wage low ed.1 & 284 & 9.36 & 14127 & 9.28 & 0.08 & 0.80 \\
\hline Log. Wage low ed.2 & 284 & 9.42 & 14126 & 9.30 & 0.11 & 1.21 \\
\hline Log. Wage low ed.3 & 284 & 9.42 & 14116 & 9.32 & 0.10 & 1.04 \\
\hline \multicolumn{7}{|c|}{ Wages of highly educated from -1 to +3} \\
\hline Log. Wage high ed._1 & 278 & 9.64 & 13613 & 9.57 & 0.07 & 0.76 \\
\hline Log. Wage high ed._0 & 274 & 9.63 & 13631 & 9.58 & 0.05 & 0.53 \\
\hline Log. Wage high ed.1 & 266 & 9.65 & 13694 & 9.59 & 0.06 & 0.59 \\
\hline Log. Wage high ed.2 & 280 & 9.70 & 13713 & 9.60 & 0.09 & 0.88 \\
\hline Log. Wage high ed.3 & 279 & 9.71 & 13688 & 9.61 & 0.10 & 1.06 \\
\hline \multicolumn{7}{|c|}{ Share of highly educated workers in employment from -1 to +3} \\
\hline Empl.share_1 & 284 & 0.23 & 14157 & 0.19 & 0.04 & 16.31 \\
\hline Empl.share_0 & 283 & 0.24 & 14112 & 0.20 & 0.05 & 19.12 \\
\hline Empl.share1 & 284 & 0.24 & 14157 & 0.20 & 0.03 & 14.28 \\
\hline Empl.share2 & 284 & 0.24 & 14157 & 0.21 & 0.03 & 13.62 \\
\hline Empl.share3 & 284 & 0.23 & 14157 & 0.21 & 0.02 & 8.99 \\
\hline \multicolumn{7}{|c|}{ Share of highly educated workers in total wage bill from -1 to +3} \\
\hline Wb.share_1 & 284 & 0.28 & 14157 & 0.24 & 0.04 & 15.16 \\
\hline Wb.share_0 & 283 & 0.29 & 14112 & 0.24 & 0.05 & 16.97 \\
\hline Wb.share1 & 284 & 0.29 & 14157 & 0.25 & 0.04 & 12.81 \\
\hline Wb.share2 & 284 & 0.29 & 14157 & 0.25 & 0.04 & 12.88 \\
\hline Wb.share3 & 284 & 0.28 & 14157 & 0.26 & 0.03 & 9.50 \\
\hline
\end{tabular}

The sample consists of plants which were domestically owned in all the observations years before the period 1. Acquired plants became foreign owned between -0 and 1 . Non-acquired plants remained domestically owned until the period 3 . 
Table 5 Effect of foreign ownership on average wages

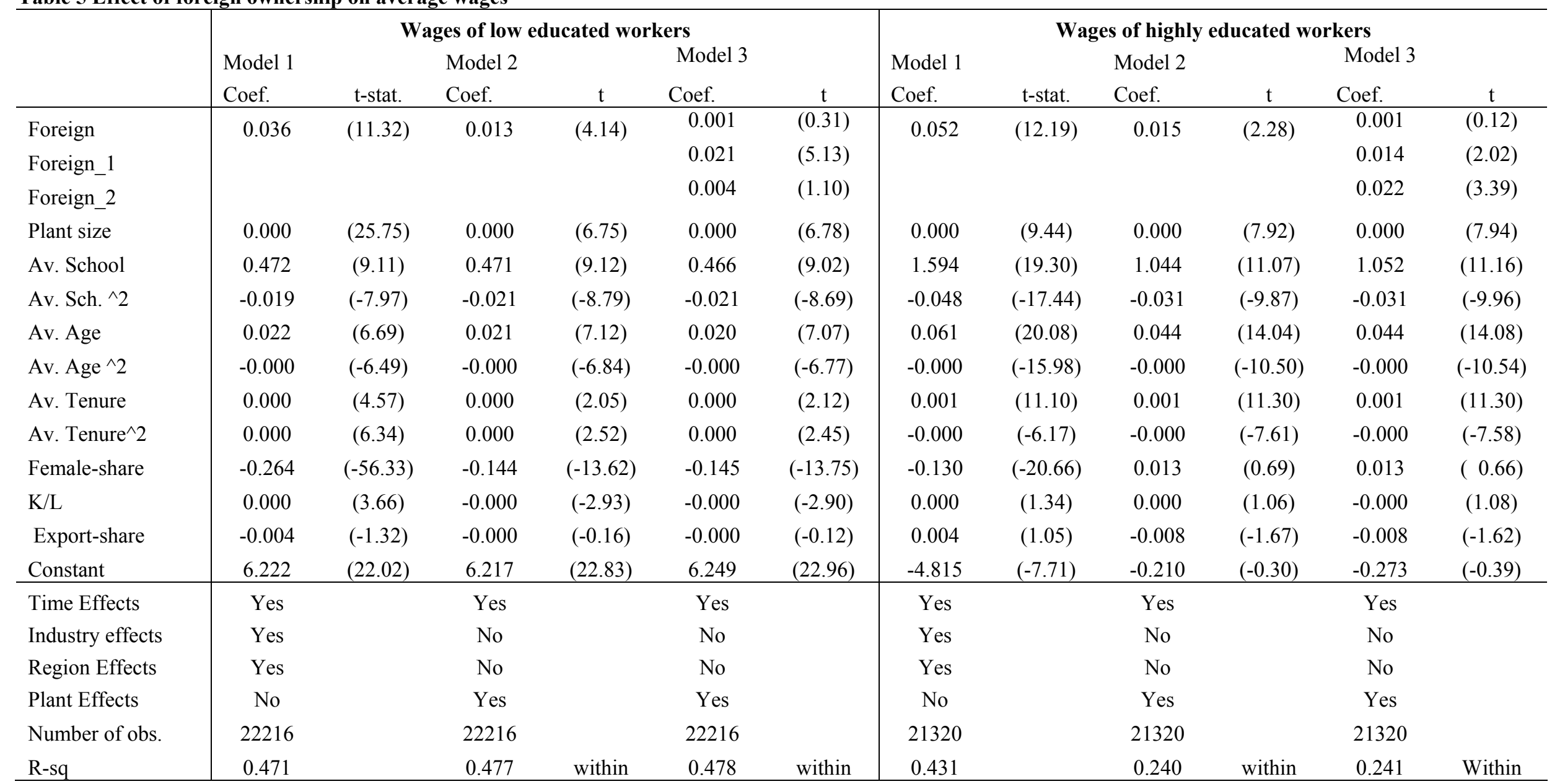

The dependent variable is the logarithm of the average monthly wage of the skill group in the plant. Schooling, age and tenure are measured as averages in the skill group in the plant Foreign is a dummy variable which indicates whether plant is foreign-owned in current year, Foreign_1 is a dummy variable which indicates whether plant was foreign owned in the previous year, and Foreign_2 is a dummy variable which indicates whether plant was foreign owned two periods before. 
Table 6 Effect of foreign ownership on share of highly educated workers in employment/total wage bill

\begin{tabular}{|c|c|c|c|c|c|c|c|c|c|c|c|c|}
\hline & \multicolumn{6}{|c|}{ Share of highly educated workers in employment } & \multicolumn{6}{|c|}{ Share of highly educated workers in wage bill } \\
\hline & \multicolumn{2}{|c|}{ Model 1} & \multicolumn{2}{|c|}{ Model 2} & \multicolumn{2}{|c|}{ Model 3} & \multicolumn{2}{|c|}{ Model 1} & \multicolumn{2}{|c|}{ Model 2} & \multicolumn{2}{|c|}{ Model 3} \\
\hline & Coef. & t-stat. & Coef. & $\mathrm{t}$ & Coef. & $\mathrm{t}$ & Coef. & t-stat. & Coef. & $\mathrm{t}$ & Coef. & $\mathrm{t}$ \\
\hline Foreign & 0.014 & $(4.43)$ & 0.005 & $(2.14)$ & 0.006 & $(2.03)$ & 0.018 & $(5.29)$ & 0.005 & $(2.11)$ & 0.006 & $(1.94)$ \\
\hline Foreign_1 & & & & & 0.003 & $(0.93)$ & & & & & 0.003 & $(0.99)$ \\
\hline Foreign_2 & & & & & -0.006 & $(-1.96)$ & & & & & -0.006 & $(-1.87)$ \\
\hline $\log \left(\mathrm{W}_{\text {hed }} / \mathrm{W}_{\text {led }}\right)$ & 0.035 & $(7.83)$ & -0.011 & $(-3.24)$ & -0.011 & $(-3.22)$ & 0.177 & $(36.68)$ & 0.122 & $(32.56)$ & 0.123 & $(32.57)$ \\
\hline $\log (\mathrm{K})$ & -0.018 & $(-20.15)$ & 0.000 & $(0.24)$ & 0.000 & $(0.23)$ & -0.018 & $(-18.78)$ & 0.000 & $(0.10)$ & 0.000 & $(0.09)$ \\
\hline $\log (Y)$ & 0.001 & $(0.52)$ & -0.006 & $(-5.11)$ & -0.006 & $(-5.10)$ & -0.000 & $(-0.16)$ & -0.007 & $(-5.69)$ & -0.007 & $(-5.68)$ \\
\hline Log(sales) & 0.030 & $(19.08)$ & 0.002 & $(1.65)$ & 0.002 & $(1.65)$ & 0.033 & $(19.45)$ & 0.002 & $(1.80)$ & 0.002 & $(1.79)$ \\
\hline Export-share & 0.020 & $(5.56)$ & 0.004 & $(1.06)$ & 0.004 & $(1.03)$ & 0.022 & $(5.66)$ & 0.004 & $(1.09)$ & 0.004 & $(1.06)$ \\
\hline Constant & -0.001 & $(-0.01)$ & 0.243 & $(17.19)$ & 0.243 & $(17.21)$ & -0.050 & $(-0.59)$ & 0.261 & (17.19) & 0.261 & $(17.21)$ \\
\hline Time Effects & Yes & & Yes & & Yes & & Yes & & Yes & & Yes & \\
\hline Industry effects & Yes & & No & & No & & Yes & & No & & No & \\
\hline Region Effects & Yes & & No & & No & & Yes & & No & & No & \\
\hline Plant Effects & No & & Yes & & Yes & & No & & Yes & & Yes & \\
\hline Observations & 20424 & & 20424 & & 20424 & & 20424 & & 20424 & & 20424 & \\
\hline R-sq & 0.194 & & 0.055 & within & 0.055 & within & 0.238 & & 0.089 & within & 0.089 & within \\
\hline
\end{tabular}

The dependent variable is the employment or wage bill share of highly educated workers in a plant. Foreign is a dummy variable which indicates whether plant is foreign-owned in current year, Foreign_1 is a dummy variable which indicates whether plant was foreign owned in the previous year, and Foreign_2 is a dummy variable which indicates whether plant was foreign owned two periods before. 
Table 7 Probit model to estimate the propensity score

Dependent variable: Probability of foreign acquisition

\begin{tabular}{lccc} 
& Coef. & Std. Err. & $\mathrm{P}>\mathrm{Z}$ \\
\hline Plant size_0 & -0.001 & 0.000 & 0.035 \\
(Plant size_0) $^{2}$ & 0.000 & 0.000 & 0.229 \\
Log(sales)_0 & 0.113 & 0.030 & 0.000 \\
Export/sales_0 & 1.063 & 0.321 & 0.001 \\
(Export/sales_0) $^{2}$ & -0.765 & 0.345 & 0.027 \\
Industry exporter-share_0 & -1.150 & 0.213 & 0.000 \\
Industry foreign-share_0 & 1.632 & 0.272 & 0.000 \\
Log(Y'rogion_0 & 0.014 & 0.029 & 0.621 \\
Log(wage)_1 & 0.084 & 0.200 & 0.673 \\
Av. School_1 & 0.076 & 0.035 & 0.031 \\
Av. Age_1 & -0.018 & 0.013 & 0.163 \\
Av. Tenure_1 & 0.104 & 0.028 & 0.000 \\
(Av. Tenure_1) & -0.002 & 0.001 & \\
Ind. Dummies & Yes & & \\
Region dummies & Yes & & \\
Year dummied & Yes & & \\
Pseudo r-square & 0.151 & & \\
LR chi2(31) & 423.41 & 100.00 & \\
Observations & 14441 & 1.97 & \\
Treated & 284 & 98.03 & \\
Control & 14157 & & \\
\hline
\end{tabular}

The sample consists of plants which were domestically owned in all the observations years before the possible acquisition. The explanatory variables are from pre-acquisition periods. _ 0 in end of the variable refers to period just before the acquisition (0), and _ 1 to period 1-2 years before the acquisition $(-1)$. 
Table 8 Effect of foreign acquisition on average wages of low educated workers: matching sample

\begin{tabular}{|c|c|c|c|c|c|c|}
\hline \multirow{2}{*}{$\begin{array}{l}\text { Method: } \\
\text { Outcome }\end{array}$} & \multicolumn{3}{|c|}{ Cross-section matching } & \multicolumn{3}{|c|}{ Difference-in-differences matching } \\
\hline & Regression (OLS) & Nearest- Neighbor & Kernel & Regression (OLS) & Nearest- Neighbor & Kernel \\
\hline \multicolumn{7}{|c|}{ Log. average wage at $t=1$} \\
\hline ATT & -0.012 & -0.024 & 0.056 & 0.000 & -0.002 & 0.001 \\
\hline t-stat & $(-1.86)$ & $(-1.53)$ & $(5.48)$ & $(-0.08)$ & $(-0.18)$ & $(0.15)$ \\
\hline Treated & & 280 & 280 & & 280 & 280 \\
\hline Controls (obs.) & $(13867)$ & 268 & 13637 & $(13867)$ & 268 & 13637 \\
\hline \multicolumn{7}{|c|}{ Log. average wage at $t=2$} \\
\hline ATT & 0.030 & 0.021 & 0.097 & 0.042 & 0.043 & 0.043 \\
\hline t-stat & $(4.54)$ & $(1.41)$ & $(8.99)$ & $(7.06)$ & $(3.88)$ & $(5.17)$ \\
\hline Treated & & 280 & 280 & & 280 & 280 \\
\hline Controls (obs.) & $(13867)$ & 268 & 13637 & $(13867)$ & 268 & 13637 \\
\hline \multicolumn{7}{|c|}{ Log. average wage at $t=3$} \\
\hline ATT & 0.014 & 0.004 & 0.079 & 0.025 & 0.026 & 0.025 \\
\hline t-stat & $(2.06)$ & $(0.29)$ & $(9.69)$ & $(4.04)$ & $(2.30)$ & $(3.25)$ \\
\hline Treated & & 280 & 280 & & 280 & 280 \\
\hline Controls (obs.) & $(13867)$ & 268 & 13637 & $(13867)$ & 268 & 13637 \\
\hline
\end{tabular}

Controls (obs.)

$(13867)$

13637

$(13867)$

13637

Table 9 Effect of foreign acquisition on average wages of highly educated workers: matching sample

\begin{tabular}{|c|c|c|c|c|c|c|}
\hline \multirow{2}{*}{$\begin{array}{l}\text { Method: } \\
\text { Outcome }\end{array}$} & \multicolumn{3}{|c|}{ Cross-section matching } & \multicolumn{3}{|c|}{ Difference-in-differences matching } \\
\hline & Regression (OLS) & Nearest- Neighbor & Kernel & Regression (OLS) & Nearest- Neighbor & Kernel \\
\hline \multicolumn{7}{|c|}{ Log. average wage at $t=1$} \\
\hline ATT & -0.010 & 0.002 & 0.051 & 0.005 & -0.002 & 0.005 \\
\hline t-stat & $(-0.88)$ & $(0.09)$ & $(3.94)$ & $(0.50)$ & $(-0.14)$ & $(0.34)$ \\
\hline Treated & & 261 & 261 & & 261 & 261 \\
\hline Controls (obs.) & $(13271)$ & 248 & 12504 & $(13271)$ & 248 & 12504 \\
\hline \multicolumn{7}{|c|}{ Log. average wage at $t=2$} \\
\hline ATT & 0.017 & 0.030 & 0.079 & 0.032 & 0.026 & 0.033 \\
\hline t-stat & $(1.44)$ & $(1.73)$ & $(7.42)$ & $(3.03)$ & $(1.52)$ & $(2.09)$ \\
\hline Treated & & 261 & 261 & & 261 & 261 \\
\hline Controls (obs.) & $(13271)$ & 248 & 12504 & $(13271)$ & 248 & 12504 \\
\hline \multicolumn{7}{|c|}{ Log. average wage at $t=3$} \\
\hline ATT & 0.014 & 0.027 & 0.084 & 0.029 & 0.023 & 0.038 \\
\hline t-stat & $(1.24)$ & $(1.55)$ & $(6.21)$ & $(2.60)$ & $(1.41)$ & $(2.70)$ \\
\hline Treated & & 261 & 261 & & 261 & 261 \\
\hline Controls (obs.) & $(13271)$ & 248 & 12504 & $(13271)$ & 248 & 12504 \\
\hline
\end{tabular}

First 3 columns in tables report the results of regression and matching analysis where the dependent variable is the level of outcome (wages of the skill group) in the period right after possible acquisition ( $\mathrm{t}=1$ ), 1-2 years after possible acquisition $(\mathrm{t}=2)$ and 2-3 years after the possible acquisition ( $\mathrm{t}=3$ ). Next 3 columns report the results of regression and matching analysis where the dependent variable is the difference between the outcome in the year just before the possible acquisition $(0)$ and in different post-acquisition years $(1,2$, and 3$)$. The explanatory variables in regressions are exactly the same as are used to estimate the propensity score, which is used in the matching analysis. These are reported in table 7. Common support restriction is imposed in all regressions and matching. T-statistics are reported in parenthesis. For matching results we report the boostrapped t-statistic. 
Table 10 Effect of foreign acquisition on the share of highly educated workers in employment: matching sample

\begin{tabular}{|c|c|c|c|c|c|c|}
\hline \multirow{2}{*}{$\begin{array}{l}\text { Method: } \\
\text { Outcome }\end{array}$} & \multicolumn{3}{|c|}{ Cross-section matching } & \multicolumn{3}{|c|}{ Difference-in-differences matching } \\
\hline & Regression (OLS) & Nearest- Neighbor & Kernel & Regression (OLS) & Nearest- Neighbor & Kernel \\
\hline \multicolumn{7}{|c|}{ Log. average wage at $t=1$} \\
\hline ATT & 0.004 & -0.012 & 0.027 & -0.011 & -0.017 & -0.012 \\
\hline t-stat & $(0.75)$ & $(-0.81)$ & $(2.93)$ & $(-2.20)$ & $(-1.88)$ & $(-1.29)$ \\
\hline Treated & & 283 & 283 & & 283 & 283 \\
\hline Controls (obs.) & $(13972)$ & 264 & 13671 & $(13972)$ & 264 & 13671 \\
\hline \multicolumn{7}{|c|}{ Log. average wage at $t=2$} \\
\hline ATT & 0.003 & -0.018 & 0.025 & -0.012 & -0.023 & -0.013 \\
\hline t-stat & $(0.51)$ & $(-1.20)$ & $(2.86)$ & $(-2.30)$ & $(-2.43)$ & $(-1.88)$ \\
\hline Treated & & 283 & 283 & & 283 & 283 \\
\hline Controls (obs.) & $(13972)$ & 264 & 13671 & $(13972)$ & 264 & 13671 \\
\hline \multicolumn{7}{|c|}{ Log. average wage at $t=3$} \\
\hline ATT & -0.008 & -0.028 & 0.014 & -0.023 & -0.034 & -0.025 \\
\hline t-stat & $(-1.17)$ & $(-1.90)$ & $(1.76)$ & $(-3.94)$ & $(-3.26)$ & $(-3.62)$ \\
\hline Treated & & 283 & 283 & & 283 & 283 \\
\hline Controls (obs.) & $(13972)$ & 264 & 13671 & $(13972)$ & 264 & 13671 \\
\hline
\end{tabular}

Controls (obs.)

264

1367

(13972)

283
264

13671

Table 11 Effect of foreign acquisition on the share of highly educated workers in wage bill: matching sample

\begin{tabular}{|c|c|c|c|c|c|c|}
\hline \multirow{2}{*}{$\begin{array}{l}\text { Method: } \\
\text { Outcome }\end{array}$} & \multicolumn{3}{|c|}{ Cross-section matching } & \multicolumn{3}{|c|}{ Difference-in-differences matching } \\
\hline & Regression (OLS) & Nearest- Neighbor & Kernel & Regression (OLS) & Nearest- Neighbor & Kernel \\
\hline \multicolumn{7}{|c|}{ Log. average wage at $t=1$} \\
\hline ATT & 0.005 & -0.011 & 0.029 & -0.010 & -0.017 & -0.012 \\
\hline t-stat & $(0.71)$ & $(-0.70)$ & $(2.91)$ & $(-2.07)$ & $(-1.88)$ & $(-1.59)$ \\
\hline Treated & & 283 & 283 & & 283 & 283 \\
\hline Controls (obs.) & $(13972)$ & 264 & 13671 & $(13972)$ & 264 & 13671 \\
\hline \multicolumn{7}{|c|}{ Log. average wage at $t=2$} \\
\hline ATT & 0.005 & -0.016 & 0.029 & -0.010 & -0.022 & -0.012 \\
\hline t-stat & $(0.70)$ & $(-1.00)$ & $(3.05)$ & $(-1.86)$ & $(-2.31)$ & $(-1.80)$ \\
\hline Treated & & 283 & 283 & & 283 & 283 \\
\hline Controls (obs.) & $(13972)$ & 264 & 13671 & $(13972)$ & 264 & 13671 \\
\hline \multicolumn{7}{|c|}{ Log. average wage at $t=3$} \\
\hline ATT & -0.006 & -0.026 & 0.019 & -0.021 & -0.032 & -0.022 \\
\hline t-stat & $(-0.84)$ & $(-1.59)$ & $(2.00)$ & $(-3.43)$ & $(-3.03)$ & $(-2.68)$ \\
\hline Treated & & 283 & 283 & & 283 & 283 \\
\hline Controls (obs.) & $(13972)$ & 264 & 13671 & $(13972)$ & 264 & 13671 \\
\hline
\end{tabular}

First 3 columns in tables report the results of regression and matching analysis where the dependent variable is the level of outcome (employment or wage bill share) in the period right after possible acquisition $(\mathrm{t}=1), 1-2$ years after possible acquisition $(\mathrm{t}=2)$ and 2-3 years after the possible acquisition ( $\mathrm{t}=3$ ). Next 3 columns report the results of regression and matching analysis where the dependent variable is the difference between the outcome in the year just before the possible acquisition (0) and in different post-acquisition years $(1,2$, and 3$)$. The explanatory variables in regressions are exactly the same as are used to estimate the propensity score, which is used in the matching analysis. These are reported in table 7 . Common support restriction is imposed in all regressions and matching. T-statistics are reported in parenthesis. For matching results we report the boostrapped t-statistic. 


\section{Table 12 Effect of foreign acquisition on average wages by educational category: difference-in-differences matching results}

\begin{tabular}{|c|c|c|c|c|c|c|c|c|c|}
\hline \multicolumn{10}{|c|}{$\begin{array}{c}\text { Difference-in-differences matching/regression results: } \\
\text { Regression (OLS) }\end{array}$} \\
\hline Education: & ATT & t-stat & Obs. & ATT & t-stat & Treat/contr & ATT & t-stat & Treat/contr \\
\hline \multicolumn{10}{|c|}{ Basic education } \\
\hline $\mathrm{T}=1$ & -0.005 & $(-0.89)$ & 13500 & -0.011 & $(-1.03)$ & $269 / 254$ & -0.003 & $(-0.29)$ & $269 / 13249$ \\
\hline $\mathrm{T}=2$ & 0.035 & $(5.19)$ & 13500 & 0.028 & $(2.68)$ & $269 / 254$ & 0.036 & $(4.02)$ & $269 / 13249$ \\
\hline $\mathrm{T}=3$ & 0.023 & $(3.21)$ & 13500 & 0.022 & $(1.87)$ & $269 / 254$ & 0.021 & $(2.12)$ & \\
\hline \multicolumn{10}{|c|}{ Vocational education } \\
\hline $\mathrm{T}=1$ & 0.003 & $(0.54)$ & 13742 & -0.002 & $(-0.16)$ & $275 / 262$ & 0.005 & $(0.42)$ & $275 / 13597$ \\
\hline $\mathrm{T}=2$ & 0.042 & $(6.61)$ & 13742 & 0.045 & $(3.67)$ & $275 / 262$ & 0.044 & $(3.55)$ & $275 / 13597$ \\
\hline $\mathrm{T}=3$ & 0.025 & $(3.68)$ & 13742 & 0.022 & $(2.00)$ & $275 / 262$ & 0.025 & $(2.22)$ & $275 / 13597$ \\
\hline \multicolumn{10}{|c|}{ Lower university education } \\
\hline $\mathrm{T}=1$ & 0.005 & $(0.49)$ & 13145 & -0.001 & $(-0.08)$ & $259 / 248$ & 0.005 & $(0.38)$ & $259 / 12450$ \\
\hline $\mathrm{T}=2$ & 0.032 & $(3.13)$ & 13145 & 0.022 & $(1.18)$ & $259 / 248$ & 0.035 & $(2.67)$ & $259 / 12450$ \\
\hline $\mathrm{T}=3$ & 0.030 & $(2.78)$ & 13145 & 0.018 & $(1.03)$ & $259 / 248$ & 0.040 & $(2.99)$ & $259 / 12450$ \\
\hline \multicolumn{10}{|c|}{ Higher university education } \\
\hline $\mathrm{T}=1$ & 0.032 & $(1.80)$ & 6648 & -0.000 & $(-0.01)$ & $163 / 169$ & 0.030 & $(1.01)$ & $169 / 5850$ \\
\hline $\mathrm{T}=2$ & 0.044 & $(2.22)$ & 6648 & 0.011 & $(0.31)$ & $163 / 169$ & 0.039 & $(1.29)$ & $169 / 5850$ \\
\hline $\mathrm{T}=3$ & 0.055 & $(2.56)$ & 6648 & 0.045 & $(1.24)$ & $163 / 169$ & 0.054 & $(1.90)$ & $169 / 5850$ \\
\hline
\end{tabular}

Common support restriction is imposed in all regressions and matching. The dependent variables is the pre-and post acquisition difference in the logarithm of the average earnings of the educational category in a plant. $\mathrm{T}=1$ refers to difference between the pre-acquisition wages (period 0 ) and the wages at the period just after acquisition ( 1 ). $\mathrm{T}=2$ refers to difference between the pre-acquisition wages and the wages at the period 1-2 years after acquisition (2). T=3 refers to difference between the pre-acquisition wages and the wages at the period 2-3 years after acquisition (3). The explanatory variables in regressions are exactly the same as are used to estimate the propensity score, which is used in the matching analysis. These are reported in table 7. Common support restriction is imposed in all regressions and matching. T-statistics are reported in parenthesis. For matching results we report the boostrapped tstatistic. 